\title{
VIRTUAL CURRENCY SEBAGAI TANTANGAN DAN PELUANG TERHADAP ASPEK SOSIAL
}

\author{
VIRTUAL CURRENCY AS A CHALLENGE AND OPPORTUNITY \\ FOR SOCIAL ASPECT
}

\author{
Agus Tri Darmawanto \\ Universitas Borneo Tarakan \\ E mail : tridrm7@gmail.com
}

\begin{abstract}
Abstrak: Tujuan dari tulisan artikel ilmiah ini untuk mengetahui virtual currency sebagai tantangan dan peluang terhadap aspek sosial. Tantangan adanya virtual currency dilihat dari aspek sosial yang antara lain adalah sebagai berikut: (i) Kriminalitas akan meraja lela, seperti pencucian uang, pendanaan teorisme, penipuan (tidak secara jelas pengelolanya dan tidak dalam pengawasan OJK dan Bank Indonesia); (ii) Tingkat kepercayaan masyarakat terhadap mata uang rupiah semakin pudar dan lebih tergiur dengan virtual currency dalam melakukan transaksi;(iii) Keamanan dan kenyamanan yang kurang dirasakan masyarakat untuk berbisnis dalam virtual currency, karena terdapat dalam dunia maya dengan risiko yang tinggi. Adapun peluang-peluang dengan adanya virtual currency dilihat dari aspek sosial antara lain sebagai berikut:.(i) Bank Indonesia dan OJK, selaku lembaga yang bergerak dalam menjaga kestabilan moneter dan pengawasan sektor jasa keuangan dengan melakukan sosialisasi kepada masyarakat untuk memberikan pengetahuan dan wawasan berkaitan dengan virtual currency; (ii) Bank Indonesia bekerjasama dengan perguruan tinggi dapat melakukan pendidikan literasi khususnya kepada mahasiswa-mahasiswa berkaitan dengan virtual currency. Dengan keberadaan virtual currency yang berkembang cukup pesat ini perlu adanya ketegasan dari seluruh elemen masyarakat maupun institusi untuk menolak adanya virtual currency berkembang di Indonesia.
\end{abstract}

Kata Kunci : Virtual Currency, Kriminalitas, Kepercayaan Masyarakat, Keamanan dan Kenyamanan, Pendidikan literasi

Abstract: The purpose of writing this scientific article is to find out the virtual currency as a challange and opportunity for social aspects. The challanges of the virtual currency seen from the social aspect are as follows: (i) criminality will be rampant, such as money laundering, terrorism funding, fraud (not clearly managing and not under the supervision of the OJK and Bank Indonesia, (ii) the level of public trust in the currency of the rupiah is fading and more attractive with the virtual currency in making transactions, (iii) security and comfort that is less felt by the community to do business in a virtual currency, because it is in the virtual world with high risk. The opportunities with virtual currency viewed from the social aspects are as follows: (i) Bank Indonesia and the OJK, as institutions that are engaged in maintaining monetary stability and supervision of the financial services sector by disseminating information to the public to provide 
knowledge and insights related to the virtual currency. (ii)Bank Indonesia in collaboration with universities can carry out literacy education specifically for students related to the virtual currency. With the existence of a virtual currency that is growing rapidly enough, there needs to be firmness from all elements of society and institutions to reject the existence of a virtual currency developing in Indonesia.

Keyword: Virtual Currency, Criminality, Puclic Trust, Safety and Comfort, literacy Education

\section{LATAR BELAKANG}

Indonesia merupakan negara yang berkembang yang terus melakukan perubahan dalam rangka pembangunan di berbagai bidang. Salah satunya bidang teknologi informasi yang saat ini memiliki perkembangan yang sangat cepat seperti intenet. Fenomena teknologi informasi berkembang diseluruh dunia, baik negara yang sudah maju maupun negara berkembang. Hadirnya teknologi diharapkan mendapatkan kedudukan yang penting kemajuan suatu negara.

Teknologi informasi saat ini sedang marak digunakan untuk berbagai macam bisnis atau yang dikenal dengan bisnis online. Bisnis pada dunia maya sudah banyak dilakukan oleh masyarakat di seluruh dunia. Termasuk dalam hal ini dalam transaksi pembayaran secara on line maupun pembayaran dengan menggunakan uang digital.

Saat ini, digital atau virtual currency digunakan sebagai lahan bisnis, dimana dengan model melakukan spekulasi mencari selisih harga yang tujuannya untuk mencari profit. Dengan cara membeli mata uang digital pada saat harga turun dan menjualnya kembali pada saat harga naik atau tinggi. Meskipun nilai tukar mata uang digital selalu berfluktuasi dari menit ke menit hingga saat ini sedang marak dan berkembang di Indonesia.

Sebagaimana telah diamanatkan oleh Deputi Gubernur Bank Indonesia (BI) Ronald Waas menyampaikan, BI sudah memiliki Peraturan tentang mata uang yaitu melalui Undang-Undang RI No. 7 Tahun 2011 tentang Mata Uang serta Undang-Undang No. 23 Tahun 1999 tentang Bank Indonesia bahwa "Mata uang yang berlaku di wilayah NKRI adalah rupiah".

Keberadaan uang digital (virtual currency) yang kini hadir di tengah masyarakat Indonesia sangatlah mengkhawatirkan. Karena, dapat digunakan dalam melakukan transaksi jual beli dengan menggunakan uang digital. Padahal apabila kita ketahui bahwa uang rupiah secara resmi sebagai alat untuk melakukan transaksi. Terlebih virtual currency seperti Bit coin yang merupakan selama ini digunakan sebagai mata uang untuk melakukan transaksi atau pembayaran. Hal ini tentu saja, tidaklah sah karena bertentangan $\begin{array}{lll}\text { dengan Undang-Undang RI No.7 } & \text { RI }\end{array}$ tentang mata uang dan UndangUndang No.23 Tahun 1999.

Masih banyak dengan kehadiran virtual currency ini dapat mempengaruhi berbagai aspek, yang 
antara lain: aspek ekonomi, sosial, budaya, regulasi dan sebagainya. Dalam tulisan ini, penulis lebih memfokuskan pada aspek sosial.

\section{RUMUSAN MASALAH}

Rumusan masalah dalam tulisan ini adalah: Bagaimana virtual currency sebagai tantangan dan peluang terhadap aspek sosial?

\section{TUJUAN PENELITIAN}

Untuk mengetahui virtual currency sebagai tantangan dan peluang terhadap aspek sosial.

\section{TINJAUAN PUSTAKA}

\section{Pengertian Virtual Currency}

Virtual Currency didefinisikan representasi nilai digital, yang dikeluarkan oleh pengembang swasta dan didenominasi dalam unit akun mereka sendiri. Virtual currenc dapat diperoleh, disimpan, diakses, dan ditransaksikan secara elektronik, dan dapat digunakan untuk berbagai tujuan, selama bertransaksi pihak setuju untuk menggunakannya. Konsep Virtual Currency mencakup lebih banyak "mata uang", mulai dari IOUs sederhana dari penerbit (seperti kupon internet atau seluler dan mil maskapai penerbangan), Virtual Currency yang didukung oleh aset seperti emas, 3 dan "cryptocurrency" seperti Bitcoin. (International Monetary Fund, 2016).

Menurut Sofian (2016), bitcoin merupakan mata uang digital yang muncul pertama kali pada tahun 2009, setelah dipublikasi pada forum komputer oleh seorang pakar kriptografi yang dikenal dengan nama Sathosi Nakamoto.

Macam-Macam Virtual Currency

Adapun jenis-jenis pembayaran digital (virtual currency) terdiri dari 2 macam, yang pertama virtual currency dalam bentuk uang digital seperti uang yang digunakan pada aplikasi video game, telkomsel cash, XL tunai, Indosat Dompetku, dan beberapa alat pembayaran digital lainnya. Jenis virtual currency ini bersifat tersentralisasi, diatur dan dikelola oleh suatu lembaga maupun perusahaan (Conway, 2014). Yang kedua adalah virtual currency yang menggunakan teknologi kriptografi atau dikenal dengan sebutan cryptocurrency dimana untuk setiap transaksi data akan dilakukan penyandian menggunakan algoritma kriptografi tertentu. Untuk saat ini baru bitcoin satu-satunya cryptocurrency pertama yang telah banyak diterapkan dan digunakan secara luas, bahkan banyak sekali sekarang bermunculan jenis cryptocurrency lain pengembangan dari protokokol bitcoin.

Perbandingan Virtual Currency di Indonesia dan Beberapa Negara

\section{$\underline{\text { Negara Jepang (Menerima Bitcoin) }}$}

Negara jepang tidak ada hukum yang mengatur berkaitan dengan Bitcoin. Sebagaimana telah dikemukakan oleh Gubernur Bank of Japan (BOJ) Haruhiko Kuroda, "Researching issues of Bitcoin, but I have nothing to say regarding Bitcoins at the moment". Negara Jepang mengeluarkan pengumuman bahwa Bitcoin merupakan mata uang yang sah untuk ditransaksikan. Sebagaimana 
regulasi Bitcoin di Negara Jepang akan diatur oleh lembaga yang juga mengelola peredaran mata uang yen, yaitu bernama Financial Services Agency. Hal tersebut juga disambut oleh salah satu perusahaan hiburan terbesar di Jepang, yakni DMM (yang membawahi berbagai situs game populer di jepang seperti Kadokawa Games), langsung merespons dengan menggunakan Bitcoin untuk semua transaksi produk dan layanannya. Pertukaran Virtual currency harus tunduk terhadap Financial Action Task Force (FATF) yang mana sebagai pintu gerbang untuk penukaran terhadap Fiat Currency.

(Media Release, 2016)

\section{$\underline{\text { Negara China (Menolak Bitcoin) }}$}

Lembaga keuangan di China dilarang untuk berurusan dengan uang digital, tapi orang-orang bebas untuk menggunakannya. Regulator Cina memperingatkan risiko yang berkaitan dengan mata uang digital. Dalam sebuah pernyataan, lima departemen pemerintah, termasuk bank sentral, Bitcoin tidak dikeluarkan oleh otoritas moneter dan tidak memiliki fungsi mata uang.125 Menurut Yao Qian, pejabat bank sentral terkemuka pusat riset mata uang digital, hingga saat ini penelitian lebih lanjut tentang Bitcoin masih terus dilakukan di China.126 Pasar Bitcoin China merupakan salah satu yang terbesar di dunia meskipun terdapat pelarangan penggunaan dalam Lembaga Keuangan China. (Media Release, 2016).

\section{METODOLOGI PENELITIAN}

\author{
Metode Pengumpulan Data dan \\ Analisis Data \\ $\underline{\text { Jenis Penelitian }}$
}

Jenis penelitian ini merupakan penelitian kualitatif. Sebagaimana dikemukakan oleh Moleong (2013), penelitian kualitatif adalah prosedur penelitian yang menghasilkan data deskriptif.

\section{$\underline{\text { Sumber dan Jenis Data }}$}

Yang dimaksud sumber data dalam penelitian adalah subyek darimana data yang diperoleh. Adapun sumber dan jenis data yang digunakan dalam penelitian ini dengan menggunakan data sekunder. Menurut Sugiyono (2017) sumber data sekunder merupakan sumber yang tidak langsung memberikan data kepada pengumpul data, misalnya orang lain atau lewat dokumen.

\section{$\underline{\text { Teknik Pengumpulan Data }}$}

Teknik pengumpulan data dalam penelitian ini adalah sebagai berikut:

a. Dokumentasi

Pengumpulan data yang diperoleh merupakan data sekunder dengan cara dokumentasi. Dokumentasi dilakukan dengan melihat dokumen-dokumen yang berkaitan dengan penelitian yang dikaji.

b. Penelitian kepustakaan (Library Research)

Penelitian kepustakaan dilakukan untuk memperoleh data berupa 
teori-teori yang dibutuhkan peneliti dalam melakukan penelitian. Data tersebut dapat diperoleh dari bukubuku yang berhubungan dengan penelitian dan jurnal penelitian terdahulu sebagai media pendukung yang diperlukan dalam penelitian ini.

\section{$\underline{\text { Analisis Data }}$}

Analisis data kualitatif merupakan upaya yang dilakukan dengan jalan bekerja dengan data, mengorganisir data, memilah-milah menjadi satuan yang dapat dikelola, mensistesiskan, mencari dan menemukan pola, menemukan yang penting dan apa yang diceritakan kepada orang lain.

Adapun teknik analisis data yang digunakan adalah Content Analysis. Sebagaimana yang dimaksud dengan Content Analysis yaitu teknik analisis untuk membuat inferensiinferensi yang dapat ditiru (Replicaple) dan sahih dengan memperhatikan konteksnnya.

\section{HASIL PENELITIAN}

Virtual Currency Sebagai Tantangan dan Peluang Terhadap Aspek Sosial

Tantangan dengan adanya Virtual Currency dilihat dari aspek sosial yang antara lain adalah sebagai berikut:

a. Kriminalitas akan meraja lela, seperti pencucian uang, pendanaan teorisme, penipuan (tidak secara jelas pengelolanya dan tidak dalam pengawasan OJK dan Bank Indonesia);

b. Kepercayaan masyarakat terhadap mata uang rupiah semakin pudar dan lebih tergiur dengan virtual currency dalam melakukan transaksi;

c. Keamanan dan kenyamanan yang kurang dirasakan masyarakat untuk berbisnis dalam virtual currency, karena terdapat dalam dunia maya dengan risiko yang tinggi.

Adapun peluang-peluang dengan adanya Virtual Currency dilihat dari aspek sosial yang antara lain adalah sebagai berikut:

a. Bank Indonesia dan OJK, selaku lembaga yang bergerak dalam menjaga kestabilan moneter dan pengawasan sektor jasa keuangan dengan melakukan sosialisasi kepada masyarakat untuk memberikan pengetahuan dan wawasan berkaitan dengan virtual currency;

b. Bank Indonesia bekerjasama dengan Perguruan Tinggi dapat melakukan pendidikan literasi khususnya kepada mahasiswamahasiswa berkaitan dengan virtual currency.

Melihat dari berbagai tantangan tersebut, virtual currency memberikan banyak sisi yang negatif dalam kehidupan sosial. Oleh karena itu, dengan keberadaan virtual currency yang berkembang cukup pesat ini perlu adanya ketegasan dari seluruh elemen masyarakat maupun institusi untuk menolak adanya virtual currency berkembang di Indonesia. Hal ini seperti halnya yang dilakukan oleh Negara Cina yang telah menolak berkembangnya virtual currency di Negaranya. 


\section{KESIMPULAN DAN SARAN}

$\underline{\text { Kesimpulan }}$

Tantangan adanya virtual currency dilihat dari aspek sosial yang antara lain adalah sebagai berikut: (i) Kriminalitas akan meraja lela, seperti pencucian uang, pendanaan teorisme, penipuan (tidak secara jelas pengelolanya dan tidak dalam pengawasan OJK dan Bank Indonesia); (ii) Tingkat kepercayaan masyarakat terhadap mata uang rupiah semakin pudar dan lebih tergiur dengan virtual currency dalam melakukan transaksi;(iii) Tingkat keamanan dan kenyamanan yang kurang bagi masyarakat, karena terdapat dalam dunia maya dengan risiko investasi yang tinggi. Adapun peluang-peluang dengan adanya virtual currency dilihat dari aspek sosial antara lain sebagai berikut:.(i) Bank Indonesia dan OJK, selaku lembaga yang bergerak dalam menjaga kestabilan moneter dan pengawasan sektor jasa keuangan dengan melakukan sosialisasi kepada masyarakat untuk memberikan pengetahuan dan wawasan berkaitan dengan virtual currency; (ii) Bank Indonesia bekerjasama dengan Perguruan Tinggi dapat melakukan pendidikan literasi khususnya kepada mahasiswa-mahasiswa berkaitan dengan virtual currency.

Dengan keberadaan virtual currency yang berkembang cukup pesat ini perlu adanya ketegasan dari seluruh elemen masyarakat maupun institusi untuk menolak adanya virtual currency berkembang di Indonesia. $\underline{\text { Saran }}$

1. Perlu adanya ketegasan regulasi untuk menolak adanya keberadaan virtual currency yang berkembang di Indonesia.

2. Disarankan bagi peneliti lain untuk dapat melakukan penelitian selanjutnya dengan melihat dari aspek-aspek lainnya.

\section{DAFTAR PUSTAKA}

He, Dong, dkk. 2016. Virtual Currencies and Beyond Initial. IMF: staff team Considerations.

MediaRelease http://www.mas.gov.sg/newsand publications/mediareleases/2014/mas-to-regulatevirtual-currencyintermediaries-for-moneylaundering-and-terroristfinancing-risks.aspx diakses 24 November 2016.

Moleong, Lexy J.2013. Metode Penelitian Kualitatif. Edisi Revisi. Bandung : PT. Remaja Rosdakarya.

Mulyanto, Ferry.2016. Pemanfaatan Cryptocrrency Sebagai Penerapan Mata Uang Rupiah Ke Dalam Bentuk Digital Teknologi Bit Coin. Bandung: Universitas Pasundan.

Sofian, dkk.2016.Implementasi

Pembayaran Menggunakan

Bitoin Pada Toko Online

Berbasis Peer to Peer. Jurnal

Script Vol.3. No. 2 Juni 2016.

Sugiyono.2017. Metode Penelitian

Kuantitatif, Kualitatif, dan $R \& D$. Bandung: Alfabeta 